\title{
Product innovation and its influence on consumer purchasing pattern - a study on packaged dairy products in Bettiah (west Champaran, Bihar)
}

\author{
Dr. D. ASHOK ${ }^{1}$, ABHAY PRAKASH SRIWASTWA ${ }^{2}$ \\ ${ }^{1}$ Professor, VIT Business School, VIT University, Vellore - 14 \\ ${ }^{2}$ MBA - Project Student, VIT Business School, \\ VIT University, Vellore - 14
}

\begin{abstract}
This article throws light on the usage pattern and the reasons behind low sensitivity of packaged dairy products. This paragraph obtains information concerning consumers' preferences and knowledge of processing organic/dairy products. It also identifies those consumers who are most likely to get processed organic/dairy products. The objectives of this study were to examine the usage pattern, user preferences, and scopes for products change, with respect to the packaged (and branded) dairy products in the town; Bettiah, West Champaran, Bihar. The researcher has used a descriptive research study using a structured questionnaire for collecting the necessary details for research analysis. Descriptive frequencies analysis used to determine the user or household characteristics that affect the purchase order related to packaged dairy products. The study also showed that, the family size and families with higher earnings were more concerned with quality of packaged dairy product. Further, this study also revealed that, majority of the population living in rural areas still uses the unprocessed, unbranded local dairy products only, which are neither healthy nor enriched with nutrients.
\end{abstract}

Key words: Packaged Dairy Product, Innovation, and Purchasing Pattern.

\section{INTRODUCTION:}

India ranks first in the world in terms of milk production. At present, the dairy sector has an estimated consumer demand for milk and milk products at EUR 26 billion, at about 8 percent growth per annum. About 35 percent of milk produced in India has meant for processing. The organized sector (large scale dairy plants) processes about 13 million tons annually, while the unorganized sector processes about 22 million tons per annum. Besides, the raw milk production, some of the chief bi-products manufactured like: Infant milk food, malted food, condensed milk and cheese. The southern and western regions collectively contribute for 80 percent of the milk produced in India. The rapid growth of the dairy-processing industry is likely to lead to a greater demand for value-added, milk-based products, such as processed cheese, table butter, sour milk, yoghurt and ice cream. A higher demand for branded and pro-biotic milk has also led to a rise in investment for milk processing. As per Dairy India 2007, the private dairies had outpaced the cooperative sector and become the largest producers of milk in the industry and the Private dairies are contributing double the quantity of milk when compare to the cooperatives in 2011. In the development of milk production, dairy cooperatives have a major role. Many small dairy cooperatives are now full fledged milk producers; AMUL of Gujarat is one of such example. Till about year 2000, India was not on the radar screen of most international dairy companies, since India was neither a major importer nor an exporter of dairy products. Through the 70's, 80's and 90's India used to take some milk powder and butter oil as aid. Exports from India were insignificantly small. From 2000 onwards, Indian dairy products, particularly milk powder, and ghee started making their presence felt in global markets.

Nevertheless, the Indian dairy sector has started as the producer-owned and professionally-managed cooperative system. As of March 2001, India's 96,000 local dairy cooperative societies (DCS) included more than ten million farmers have integrated in a three-tiered cooperative structure. Though dairy cooperatives have found throughout India, the cooperative movement has been most successful in a few states, notably Gujarat. Gujarat's success can be attributed to a higher rate of farmer activism and more efficient political institutions. Over the years, states have developed popular dairy brands such as Amul (from Gujarat), Vijaya (from Andhra Pradesh), Verka (from Punjab), Saras (from Rajasthan), Nandini (from Karnataka), Milma (from Kerala) and Gokul (from Maharashtra). These brands have earned high degrees of brand recognition and customer confidence, especially within in their respective states. The Indian dairy industry faces challenges from the international dairy market. The Indian dairy industry had characterized by relatively high costs in milk production, processing, and marketing, and relatively poor quality of milk due to unhygienic handling, this could potentially pose a significant threat to the industry and its farmers. An Indian dairy farmer gets paid about 
Rs. 7-8 per kg. The Milk has been transfer to several levels, passing from the farmer, to the local dairy cooperative society (DCS), and the union before it pasteurized. The processed milk been transferred to retail markets through various supply chain delivery mechanisms, ultimately reaching the consumer after several levels of "middlemen." This multi-layered system not only poses hygiene issues, but each level of handling adds additional cost. Addressing these challenges and increasing the competitiveness of the Indian dairy industry will require both improved technology and better management. The innovative use of appropriate technologies can help the industry produce high-quality products at a lower cost, while professional management can ensure a more optimal utilization of the industry's human and financial resources. Technology solutions will need to address the unique needs of India's dairy supply chain, which runs from its largest cities to its smallest, most remote villages, in an integrated and the locally-relevant way. Because the Indian dairy industry supply chain extends from small villages where the milk collection happens to big cities where consumers buy dairy products, it necessarily involves people from very different backgrounds who often speak dialects. India is the largest producer of milk producing more than 100 million tons of milk per annum. Yet, the per capita milk consumption in India is estimated as around $250 \mathrm{~kg}$ per day. India has a population of more than 1 billion with diverse habits, cultures, traditions and religions. Regional variations within the country can be mind boggling.

ABOUT THE STUDY AREA: Bihar has situated in the eastern part of the country (between $83^{\circ}-30^{\prime}$ to $88^{\circ}-00^{\prime}$ longitude). Bihar lies midway between the humid West Bengal in the east and the sub humid Uttar Pradesh in the west which provides it with a transitional position in respect of climate, economy and society. The Bihar has divided into two unequal halves by the river Ganga which flows through the middle from west to east. The Milk production in Bihar is approximately equal to that of Haryana and Tamilnadu. The per capita milk availability of this state is remarkably low (only 163 grams per day, as of July 2006 data). Relatively higher population is one of the reasons. The development of cooperative societies in the state has created the environment for higher milk and dairy production levels. Despite that, the milk and dairy product consumption levels are still remarkably low, which results into malnourishment of babies, youth and old-age people. A population of 8.3 Crores creates a large market for dairy products, but Bihar is still not the centre of attraction for investment from multinational dairy producers. West Champaran district, headquarters Bettiah, had a population of 30 lakhs (approx). The district borders have shared with neighbor country Nepal. The low per capita milk (\& dairy products) consumption, less level penetrations of packaged (and branded) dairy products and absence of any such study which throws light in this region, create the ground for the study. This study gas been done to explore and assess the usage pattern, consumer preferences and scopes for products innovation with respect to the packaged (and branded) dairy products in the town; Bettiah, West Champaran, Bihar.

\section{STATEMENT OF THE PROBLEM:}

This paper deals with the study of the consumers' preference for dairy products. The consumers preferences will change from brand to brand depend on quality, price, Wage, taste and like. The complications involved in identifying factors of purchasing behavior of consumer's are many. Therefore, the interest to know the degree to which consumer preference of dairy products varies with gender, age, income or other induced the selection of this study.

\section{OBJECTIVES OF THE STUDY:}

The objectives of this study are to provide for an improved understanding of those factors influencing consumer demand, for packaged (processed) food products and the purchasing pattern of dairy products.

Specific objectives of this study include:

1. To know the demographical profile of the respondents

2. To study the various factors influencing the purchasing pattern of dairy products.

3. To analyze the significance of all identified factors with respect to the purchasing decision.

\section{SIGNIFICANCE AND HYPOTHESIS OF THE STUDY:}

Today, the dairy products are vital for everyone especially milk which is essential for babies. The parents are taking care of their children by giving good quality milk. Many companies in the market are willing to capture market with modern approach using latest technology. Dairy products are different by price, quality, packaging, size etc., so it is necessary to know customers satisfaction. This study is undertaken with a view to find the factors influencing purchasing pattern of the branded dairy products 
In this study the researcher chooses the null hypotheses as shown in the table $\mathbf{1}$

Table 1 - STATEMENTS OF HYPOTHESES USED IN THIS STUDY

\begin{tabular}{|c|c|c|c|}
\hline & Category & & Hypotheses \\
\hline 1 & $\begin{array}{l}\text { Usage } \\
\text { Degree }\end{array}$ & & $\begin{array}{l}\mathrm{H}_{0} \text { : There is no significant relationship between age of family head and the } \\
\text { type of dairy products (branded or conventional) }\end{array}$ \\
\hline 2 & $\begin{array}{l}\text { Degree of } \\
\text { Importance }\end{array}$ & & $\begin{array}{l}\mathrm{H}_{0:} \text { There is no significant relationship between the age of the family head } \\
\text { and the importance given to dairy products in daily food. }\end{array}$ \\
\hline 3 & $\begin{array}{l}\text { Purchase } \\
\text { Reason }\end{array}$ & & $\begin{array}{l}\mathrm{H}_{0} \text { : there is no significant relationship between the age of the family head } \\
\text { and the reason behind the purchase of dairy products }\end{array}$ \\
\hline 4 & $\begin{array}{l}\text { Branded } \\
\text { Purchase } \\
\text { Reason }\end{array}$ & & $\begin{array}{l}\mathrm{H}_{0:} \text { there is no significant relationship between the age of the family head and } \\
\text { the reason for purchase of branded dairy products. }\end{array}$ \\
\hline 5 & $\begin{array}{l}\text { Attracting } \\
\text { Factors }\end{array}$ & & $\begin{array}{l}\mathrm{H}_{0:} \text { there is no significant relationship between the age of the family head and } \\
\text { the factors attracting towards branded dairy products. }\end{array}$ \\
\hline 6 & Regularity & \multirow{6}{*}{ 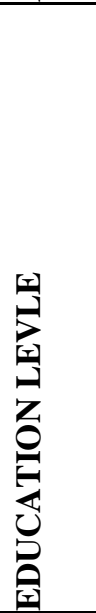 } & $\begin{array}{l}\mathrm{H}_{0:} \text { there is no significant difference between the education level of } \\
\text { customers and the type of consumers they are i.e. regular or occasional. }\end{array}$ \\
\hline 7 & $\begin{array}{l}\text { Degree of } \\
\text { Importance }\end{array}$ & & $\begin{array}{l}\mathrm{H}_{0:} \text { there is no significant relationship between the education level of } \\
\text { customers and the importance given to dairy products in daily food. }\end{array}$ \\
\hline 8 & $\begin{array}{l}\text { Awareness } \\
\text { State }\end{array}$ & & $\begin{array}{l}\mathrm{H}_{0:} \text { there is no significant relationship between the educational level of } \\
\text { customer and their awareness state about the benefits of the packaged dairy } \\
\text { products. }\end{array}$ \\
\hline 9 & $\begin{array}{l}\text { Purchase } \\
\text { Frequency }\end{array}$ & & $\begin{array}{l}\mathrm{H}_{0:} \text { there is no significant relationship between the educational level of the } \\
\text { customer and the purchase frequency of essential dairy products. }\end{array}$ \\
\hline 10 & $\begin{array}{l}\text { Attracting } \\
\text { Factors }\end{array}$ & & $\begin{array}{l}\mathrm{H}_{0:} \text { there is no significant relationship between the educational level of the } \\
\text { customer and the factors attracting towards branded dairy products. }\end{array}$ \\
\hline 11 & $\begin{array}{l}\text { Substitute } \\
\text { Action }\end{array}$ & & $\begin{array}{l}\mathrm{H}_{0} \text { : there is no significant relationship between the educational level of } \\
\text { customer and their actions, in case of unavailability of desired brand } \\
\text { products. }\end{array}$ \\
\hline 12 & Regularity & & $\begin{array}{l}\mathrm{H}_{0:} \text { there is no significant relationship between the gender of the purchase } \\
\text { decision making person and type of consumers they are, i.e. regular or } \\
\text { occasional. }\end{array}$ \\
\hline 13 & $\begin{array}{l}\text { Packaged } \\
\text { Preference }\end{array}$ & & $\begin{array}{l}\mathrm{H}_{01:} \text { there is no significant relationship between the gender of the purchase } \\
\text { decision making person and reason behind the purchase of packaged over } \\
\text { conventional dairy products. }\end{array}$ \\
\hline 14 & Regularity & \multirow{3}{*}{ 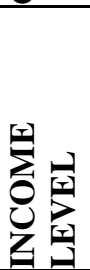 } & $\begin{array}{l}\mathrm{H}_{01:} \text { there is no significant relationship between the income level of } \\
\text { customers and the type of consumers they are i.e. regular or occasional. }\end{array}$ \\
\hline 15 & $\begin{array}{l}\text { Importance } \\
\text { Given }\end{array}$ & & $\begin{array}{l}\mathrm{H}_{01:} \text { there is no significant relationship between the income level of } \\
\text { customers and the importance given by them to diary products in daily food. }\end{array}$ \\
\hline 16 & $\begin{array}{l}\text { Purchase } \\
\text { Reason }\end{array}$ & & $\begin{array}{l}\mathrm{H}_{01 \text { : there is no significant relationship between the income level of the }} \\
\text { customers and the reason behind the purchase of packaged dairy products. }\end{array}$ \\
\hline
\end{tabular}

\section{RSEARCH METHODOLOGY:}

In this study, the researcher has used the descriptive Research to know the influence of various factors influencing the purchasing pattern with respect to packaged dairy products in the study area Bettiah, W. Champaran, Bihar. The researcher has identified all households in the study area as the population. Among the population, the required sample size was obtained using non probability sampling method. For collecting data, the researcher has used a structured questionnaire, designed for the purpose of the study. The researcher has employed various questions related to purchasing pattern observation, purchase denominations, purchase frequencies, attraction/purchase reason, awareness level and demographic variables with a rating scale, were asked. 
Prior to data collection, the researcher also shown interest to conduct a pilot study with limited samples to measure the difficulties in questionnaire format. Though, the researcher tried to get maximum sample size, due the limitation of time and respondent's cooperation, the researcher could collect only 225 valid questionnaires from the target population. The sample was evenly distributed among the respondents' people residing at rural and urban parts of the study area, covering professionals, employees, and proprietors of various small concerns, shopkeepers, villagers and housewives. The study period was fixed for the period of four months $(2010$ - 2011). All those data collected was subjected to various data analysis like percentage analysis, Chi square test and weighted average method for deriving meaningful conclusion.

\section{LIMITATIONS OF THE STUDY}

The researcher has taken care to avoid errors in the collection of data to derive the findings and conclusions of the study. In spite of all this, the present study is subject to the limitations under mention

1. Due to Budget and time constraints, the study was limited to 225 consumers spread over West Champaran, Bihar for the analysis.

2. By using questionnaire there may be a chance of receiving biased information from the respondents.

3. Some respondents were unable or unwillingly to provide information with unconscious attitudes to investigators.

\section{FINDINGS OF THE STUDY}

The analyses part of this study revealed that, the demographic profile of the respondents representing around 87 percent had reported their living place as rural and semi urban places. Nearly half of the population had reported their qualification were up to graduation level and above. The balance of 50 percent had recorded, that they qualified up to 10 th $\& 12$ th standard level of education. Regarding the gender base, nearly 52 percent of them were male respondents and balance was females. The gender ratio of respondents had recorded as 1: 0.957. This is highly significant when compared to Bihar state profile of 1: 0.921 . Further, it also confirmed that, the purchase decision made by male members have largely applied in rural parts of households, where as purchase decisions made by female members have recorded in urban based house hold. Regarding the age group of the respondents, the majority ( 44.89 percent) of respondents' reported that they were above 40 years and above and the balance of, say 55.11 per cent had come under the age groups between 21 to 40 years. Further, around 45.56 per cent of respondents had witnessed that they had smaller size family with up to 4 members and 64.45 per cent had recorded that there family size were more than four members and above. About 44.88 per cent of the respondents were earning more than Rs. 12,000/- per month, out of which, 12.44 per cent were in the category of more than Rs. 18,000/- per month and balance of them 55.11 per cent were earning up to Rs. 12,000/ per year, out of which, 9.78 per cent had come under the category of less than Rs. 3000/ per month.

The Purchasing pattern of Dairy products revealed that, among the respondents, 45 per cent had preferred to purchase any packaged dairy products based on nutrition based benefits, whereas, 35 percent had preferred over the health-related benefits and the balance of around 20 per cent had preferred to purchase dairy products based on promotional schemes attached with it. Majority of the respondents (70 per cent) had shown their preferences towards the taste of the dairy product highly influence the purchase decision, whereas, 30 per cent told they had not influenced by the taste of dairy products.

Regarding the shopping patronage, nearly 50 per cent were looking for nearby place for their purchase, where as other 50 percent were ready to purchase irrespective of the distance, out of which nearly 23 per cent had shown preference even up to five $\mathrm{km}$ radius. This showed the role of the distribution network had influenced the penetration level. Around 65 per cent had shown their preference over dairy products only if, they were free from chemical and additive based. Whereas, the balance of 34 per cent had not shown their awareness over the chemical and additives used in packaged products. This may be due to poor awareness about the issues.

Regarding the frequency of purchase of dairy product (Packaged milk, Milk Powder \& Butter), around 65 per cent had shown their interest on day-today basis, whereas others shown their interest over two to three times in a week, once in a week, once in a month and on an occasional basis respectively. The majority of them had shown their preferences towards product freshness whereas, others confined to the self life of the product. Further, the frequency of purchase of other dairy products such as, ice creams, Milk Peda and cheese, revealed that, ninety percent had purchased once in a month or occasional basis. This showed the lower level penetration of these products in the market. The purchase denominations of milk powder revealed that, around 35 per cent had demand for one $\mathrm{Kg}$ to two $\mathrm{Kg}$ of milk powder, out of which, nearly 10 per cent need for two Kg. Further, 
another 35 per cent had need only lower denominations up to 100 grams and balance of around 30 per cent had preferred to purchase between 100 grams and 500 grams. This is significant because in families having infant kids, powder milks had used to feed them as alternate to the mother's milk, and powder milk had used as dairy whitener in making tea / coffee. The purchasing pattern of Gee' product revealed that, nearly 30 per cent had demand over one or two $\mathrm{kg}$ of quantity in a month. Whereas, around 20 per cent revealed that, they had demanded for 500 grams per month and nearly 48 per cent had demanded over lesser quantity of denominations like 250 grams, 200 grams, 100 grams and less or equal to 50 grams. Similarly, for the ice creams, around 80 Per cent had showed their interest to purchase only maximum of 250 grams, and balance of 20 per cent had their demand for larger quantity and needed for family pack.

Factors influencing the purchasing pattern of the branded dairy products: Among the factors given, most of the respondents had showed their priority towards the 'availability' of the packaged dairy products, the 'freshness' of the packaged product and the 'shelf life' of the product as their first, second and third choices respectively. The 'taste' of the product and the 'advertisment' given by manufactures had showed fourth and fifth choice respectively as shown in table number 2.

It is significant from the result that dairy producers have to work on better distribution system for maintaining the "freshness" of the products and in turn achieve the greater shelf life. Further, in order to differentiate their product among the competitors, dairy producers could work on different flavours, and they should offer different ranges of tastes to the consumers. Besides every thing, it should also improve the product awareness of customers through various media choices for better reach ability in the form of advertisements and promotional offers.

\begin{tabular}{|c|c|c|c|c|c|c|c|c|}
\hline \multicolumn{9}{|c|}{$\begin{array}{c}\text { Table : } 2 \text { Weighted Average Rank } \\
\text { Major Factors Influencing the Purchasing Decision of Packaged Dairy Products }\end{array}$} \\
\hline Center weight $\rightarrow$ & 5 & 4 & 3 & 2 & 1 & & & \\
\hline Rank $\rightarrow$ & I & II & III & IV & $\mathbf{V}$ & Total & Average & $\begin{array}{l}\text { Weighted } \\
\text { rank }\end{array}$ \\
\hline \multicolumn{9}{|l|}{ Factors $\downarrow$} \\
\hline \multirow[t]{2}{*}{ Availability } & 81 & 60 & 43 & 26 & 18 & & & \\
\hline & 405 & 240 & 129 & 52 & 18 & 844 & 3.75111 & 1 \\
\hline \multirow[t]{2}{*}{ shelf life } & 41 & 57 & 63 & 37 & 27 & & & \\
\hline & 205 & 228 & 189 & 74 & 27 & 723 & 3.21333 & 3 \\
\hline \multirow[t]{2}{*}{ Freshness } & 53 & 50 & 64 & 29 & 29 & & & \\
\hline & 265 & 200 & 192 & 58 & 29 & 744 & 3.30667 & 2 \\
\hline \multirow[t]{2}{*}{ advertisement } & 12 & 22 & 28 & 93 & 70 & & & \\
\hline & 60 & 88 & 84 & 186 & 70 & 488 & 2.16889 & 5 \\
\hline \multirow[t]{2}{*}{ Taste } & 50 & 49 & 28 & 31 & 67 & & & \\
\hline & 250 & 196 & 84 & 62 & 67 & 659 & 2.92889 & 4 \\
\hline
\end{tabular}

Source: Primary Data

Relationship between the Demographical factors \& Purchasing Decision over dairy products: The relationship between various demographical factors and purchasing decisions had measured using the chisquare analysis. The results of the chi square analysis had drawn on account of the null hypothesis with due consensus of demographical factors such as, the age of the family head, the educational qualification, the gender and the monthly Income state as shown in Table Number 3.

The final results of the calculated value and table value of the analysis had showed that, 
- the age group of the respondents had showed 'significance' with only the importance given to dairy products and all other factors such as, usage of branded dairy products, reasons for purchase branded dairy products and the various factors attracting for their purchase of dairy products had shown 'no significance' with age group of respondents.

- The educational qualification had showed the significance with respondents' regular consumption pattern only. Whereas, all other factors showed, no significance with educational background.

- The Gender had shown no significance with regular consumption pattern of dairy products and reasons behind using packaged over conventional.

- The monthly income had shown the significance with regular consumption pattern of dairy products. Whereas, no significance shown on account of importance given for dairy products in their regular consumption and reasons influencing them to purchase dairy products.

Table Number 3: Chi Square Tests Results:

\begin{tabular}{|c|c|c|c|c|c|}
\hline S. no & Variable 1 & Variable 2 & $\begin{array}{l}\text { Calculated } \\
\text { value }\end{array}$ & $\begin{array}{l}\text { Table } \\
\text { value }\end{array}$ & Result \\
\hline 1 & Age of family head & usage dairy type & 18.12 & 21.03 & accept HO \\
\hline 2 & Age of family head & $\begin{array}{l}\text { importance given to dairy } \\
\text { products }\end{array}$ & 24.97 & 21.03 & reject $\mathrm{H} 0$ \\
\hline 3 & Age of family head & reason behind purchase & 17.8 & 21.03 & accept H0 \\
\hline 4 & Age of family head & reason for branded purchase & 33.06 & 36.42 & accept H0 \\
\hline 5 & Age of family head & factors attracting & 33.667 & 36.42 & accept H0 \\
\hline 6 & $\begin{array}{l}\text { Educational } \\
\text { Qualification }\end{array}$ & Regular consumer or not? & 24.09 & 15.51 & reject $\mathrm{HO}$ \\
\hline 7 & $\begin{array}{l}\text { Educational } \\
\text { Qualification }\end{array}$ & $\begin{array}{l}\text { importance given to dairy } \\
\text { products }\end{array}$ & 10.72 & 15.51 & accept $\mathrm{H} 0$ \\
\hline 8 & $\begin{array}{l}\text { Educational } \\
\text { Qualification }\end{array}$ & awareness of benefits & 5.82 & 9.49 & accept H0 \\
\hline 9 & $\begin{array}{l}\text { Educational } \\
\text { Qualification }\end{array}$ & $\begin{array}{l}\text { purchase frequency of } \\
\text { essential items }\end{array}$ & 31.38 & 36.42 & accept $\mathrm{HO}$ \\
\hline 10 & $\begin{array}{l}\text { Educational } \\
\text { Qualification }\end{array}$ & factors attracting & 15.18 & 21.03 & accept $\mathrm{H} 0$ \\
\hline 11 & $\begin{array}{l}\text { Educational } \\
\text { Qualification }\end{array}$ & $\begin{array}{l}\text { action, in case of } \\
\text { unavailability }\end{array}$ & 40 & 15.51 & reject $\mathrm{H} 0$ \\
\hline 12 & Gender & Regular consumer or not? & 0.348 & 5.99 & accept H0 \\
\hline 13 & Gender & $\begin{array}{l}\text { reason behind packaged over } \\
\text { conventional }\end{array}$ & 9.04 & 9.49 & accept H0 \\
\hline 14 & Monthly income & Regular consumer or not? & 21.886 & 21.03 & reject $\mathrm{HO}$ \\
\hline 15 & Monthly income & $\begin{array}{l}\text { importance given to dairy } \\
\text { products }\end{array}$ & 15.372 & 21.03 & accept H0 \\
\hline 16 & Monthly income & $\begin{array}{l}\text { Respondents' } \\
\text { reason }\end{array}$ & 14.875 & 21.03 & accept H0 \\
\hline
\end{tabular}

Source: Primary data

\section{Conclution:}

The pattern of consumer behaviour is highly dynamic and it is often influenced by several factors. This study reveiled that, the factors on priority to influence the consumer preferences over the branded dairy products in the study area. This study also explored the relationship of demographical factors with reference to purchasing pattern. 


\section{REFERENCES:}

[1] Hannah Jane McKnight, (2007) Organic Milk: Consumers and their purchasing patterns: Virginia Polytechnic Institute and State University.

[2] Frank H. Fuller, John C. Beghin, and Scott Rozelle, (Nov. 2004) Urban Demand for Dairy Products in China: Evidence from New Survey Data, Working Paper 04-WP 380, Center for Agricultural and Rural Development Iowa State University (www.card.iastate.edu).

[3] John C. Beghin, Dairy Markets in Asia: (Sep. 2005) An overview of recent findings and Implications, briefing Paper 05-BP 47, Center for agriculture and rural development, Iowa State University.

[4] B. K. Roy, K. S. Haque, M. R. Islam, M. Hasanuzzaman \& M. M. Rahman, (2002), Consumption Pattern of Milk and Milk Products among different income levels in some selected areas of Bangladesh, Pakistal Journal of Nutrition 1 (6): 282 - 287.

[5] Hayley H. Chouinard, David E. Davis, Jeffrey T. laFrance \& Jeffrey M. Perloff, (2005), Milk Marketing Order Winners and Losers, School of Economic Sciences, Washington State University.

[6] Suku Bhaskaran, )1996), Culture's Consequences: Dairy Market Opportunities in India, Marketing Bulletin, 7, 39 - 50.

[7] Zakowska - Biemans S, (2008), Consumers Values and Motives regarding organic food products in Poland, $16^{\text {th }}$ IFOAM organic world congress, Modena, Italy, June 16-20.

[8] Food and Beverages Survey, (2006) FICCI.

[9] Processed Food and Agribusiness: Opportunities for investment in India, (2007), A knowledge paper, FICCI and KPMG. 